\title{
Exploitation of mesoscale oceanographic features by grey-headed albatross Thalassarche chrysostoma in the southern Indian Ocean
}

\author{
D. C. $\mathrm{Nel}^{1, *}$, J. R. E. Lutjeharms ${ }^{2}$, E. A. Pakhomov ${ }^{3}$, I. J. Ansorge ${ }^{2}$, P. G. Ryan ${ }^{1}$, \\ N. T. W. Klages ${ }^{4}$

\begin{abstract}
${ }^{1}$ Percy FitzPatrick Institute and ${ }^{2}$ Department of Oceanography, University of Cape Town, Rondebosch 7701, South Africa
\end{abstract} \\ ${ }^{3}$ Southern Ocean Group, Department of Zoology \& Entomology, Rhodes University, PO Box 94, Grahamstown 6140, South Africa \\ ${ }^{4}$ Port Elizabeth Museum at Bayworld, PO Box 13147, Humewood 6013, South Africa
}

\begin{abstract}
Breeding grey-headed albatross Thalassarche chrysostoma, tracked from Marion Island (Prince Edward Islands) during November-December 1997 and January-February 1998, showed a strong association with mesoscale oceanographic features, as identified by sea surface height anomalies, in the southern Indian Ocean. During incubation, most birds foraged to the north of the island, at the edges of anomalies created by the Agulhas Return Current in the Subtropical Convergence and the Subantarctic zones. In contrast, during chick-rearing all tracked birds foraged to the southwest of the island, at the edges of anomalies along the South-West Indian Ridge. Previous work in this area has shown that these anomalies are in fact eddies that are created as the Antarctic Circumpolar Current crosses the South-West Indian Ridge. Diet samples taken during the chick-rearing period showed a predominance of fresh specimens of the predatory fish Magnisudis prionosa and the squid Martialia hyadesi. Myctophid fish and amphipods Themisto gaudichaudii, both known prey of $M$. hyadesi, were also well represented in our samples. Diet samples taken from tracked birds showed birds feeding at edges of positive anomalies returning with fresh specimens of $M$. prionosa and $M$. hyadesi. Predatory fish and squid are thus presumably concentrated at these features. Eddies formed at the South-West Indian Ridge have also been shown to drift closer to Marion Island, within the foraging range of penguins and seals breeding on Marion Island. We therefore suggest that these mesoscale oceanographic features may be an important component of the 'life-support' system enabling globally significant populations of seabirds and seals to breed at the Prince Edward Islands.
\end{abstract}

KEY WORDS: Albatross · Foraging ecology · Diet · Oceanography Resale or republication not permitted without written consent of the publisher

\section{INTRODUCTION}

Pelagic seabirds, and especially albatross, display an extreme life history, with low reproductive rates, slow chick development, delayed onset of breeding and high adult survival (Warham 1996). Lack (1968) suggested that these breeding adaptations were the result of severe limitations on the rate at which adults could

*E-mail: dnel@botzoo.uct.ac.za provide food to their chicks. These limits arise from the sparseness, patchiness and unpredictability of marine resources, as well as the large distances adults are required to travel to and from foraging areas (Ashmole 1971). It therefore follows that breeding birds should concentrate their foraging efforts in areas where resources are most predictable. Although foraging areas should ideally be located closest to their breeding colonies, in order to minimize time and energy required to travel to these areas, the closest foraging areas will also have the highest intra- and inter-specific 
competition and may also suffer local depletion first (Ricklefs 1990). It seems unlikely that pelagic seabirds and seals can deplete their stocks over the ocean as a whole, but it does seem reasonable that they are able to do this in the vicinity of their breeding colonies and in areas where prey becomes concentrated due to physical processes (Anderson \& Ricklefs 1987).

Physical and biological processes in the ocean affect the distribution and abundance of plankton and nekton, which in turn affect the distribution of seabirds and marine mammals (Piontkovski et al. 1995, Pakhomov \& McQuaid 1996). Studies have shown that seabirds are predictably concentrated at physical oceanographic features of different spatial scales, from tidal fronts through mesoscale eddies to latitudinal frontal systems, which all display increased prey availability (Haney et al. 1995, Pakhomov \& McQuaid 1996, Rodhouse et al. 1996, Hunt et al. 1999). Once at an area of enhanced biological productivity, procellariforms may use odor trails or visual clues to locate concentrations of prey (Nevitt 1999).

Albatross living in the Southern Ocean are largely reliant on pelagic fish and squid (Cherel \& Klages 1997). These prey items are patchily distributed and very little is known about the biological and environmental variables that govern their distribution (Cherel \& Weimerskirch 1995). In this paper we demonstrate how grey-headed albatross, breeding at the subAntarctic Marion Island, are able to exploit mesoscale oceanographic features $O(100 \mathrm{~km})$ to $O(1000 \mathrm{~km})$ from their breeding locality, resulting from interactions between current systems and local bathymetry. In an attempt to understand more about the ecology of these oceanographic features, we describe the diet of these birds during the chick-rearing period, when birds showed a strong association with certain oceanographic features.

\section{Physical environment}

The Prince Edward Islands, of which Marion Island is the largest, lie in the Subantarctic, between the Subtropical Convergence to the north and the Antarctic Polar Front to the south (Lutjeharms \& Valentine 1984). A secondary front, the Subantarctic Front, usually lies just to the north of the island group, but all 3 of these fronts exhibit considerable temporal changes in their latitudes (Lutjeharms 1990). Furthermore, a number of eddies of various sizes have been observed in the region, making it a complex physical environment (I.J.A. \& J.R.E.L. unpubl.). Warmer, anti-cyclonic eddies were thought to come from north of the Subantarctic Front, and this has been borne out by the observed plankton content of such features (Froneman et al.
1999). The same holds true for colder, cyclonic eddies near the islands that seem to come from south of the Antarctic Polar Front. However, these eddies are not just vehicles for carrying foreign organisms; there is evidence that they intrinsically affect the primary productivity of their waters (e.g. Perissinotto \& Duncombe Rae 1990, Ansorge et al. 1999, Froneman et al. 1999, Perissinotto et al. 2000) in ways that are not yet well understood.

The Subtropical Convergence has been shown to exhibit considerably enhanced levels of chlorophyll $a$ and zooplankton standing stock, but this enhancement seems to occur at irregular intervals (Barange et al. 1998). This is true both in regions where this front is strongly developed (Pakhomov et al. 1994) and in regions where it is weaker (Barange et al. 1998). This enhancing effect is evident in colour observations from space (e.g. Lutjeharms et al. 1985, 1986, Weeks \& Shillington 1994, Machu et al. 1999) as well as in in situ measurements (Allanson et al. 1981). However, it is not only the lowest trophic levels such as phytoplankton that are affected (Boden et al. 1988), but also fish and higher predators such as seabirds (Abrams 1983, 1985a, Abrams \& Lutjeharms 1986, Abrams \& Miller 1986).

All investigations of this type have shown that there is considerably higher mesoscale variability related to frontal systems than in other regions of the Southern Ocean. This has been shown from statistical investigations using accumulated hydrographic data (Lutjeharms \& Baker 1980), from the movement patterns of surface drifters (Daniault \& Menard 1985) and from satellite altimetry (e.g. Cheney et al. 1983). Investigations that have focused on the Subtropical Convergence have demonstrated that much of the variability here is due to the prevalence of eddies (Lutjeharms \& Valentine 1988). It has subsequently been shown that the intensity of mesoscale variability at the Subtropical Convergence diminishes from a peak south of Africa to a low value at $\sim 70^{\circ} \mathrm{E}$ (Lutjeharms \& Ansorge in press), suggesting that the prevalence and intensity of eddies at this front would also decrease.

Secondary regions of high variability are found coincident with the Antarctic Polar Front, where the core of the Antarctic Circumpolar Current crosses mid-ocean ridges (Lutjeharms \& Baker 1980, Colton \& Chase 1983). This is particularly relevant to the environment of the Prince Edward Islands. These islands lie just downstream of the South-West Indian Ridge, which is crossed by the core of the Antarctic Circumpolar Current at about $50^{\circ} \mathrm{S}, 30^{\circ} \mathrm{E}$ (Read \& Pollard 1993). Altimetric observations have shown that this specific location is a region of extraordinarily high mesoscale variability (e.g. Chenney et al. 1983, Wakker et al. 1990, Snaith \& Robinson 1996) that extends eastwards to the vicinity of the islands (see Fig. 2). The key 
(a) Sea Surface Temperature Distribution

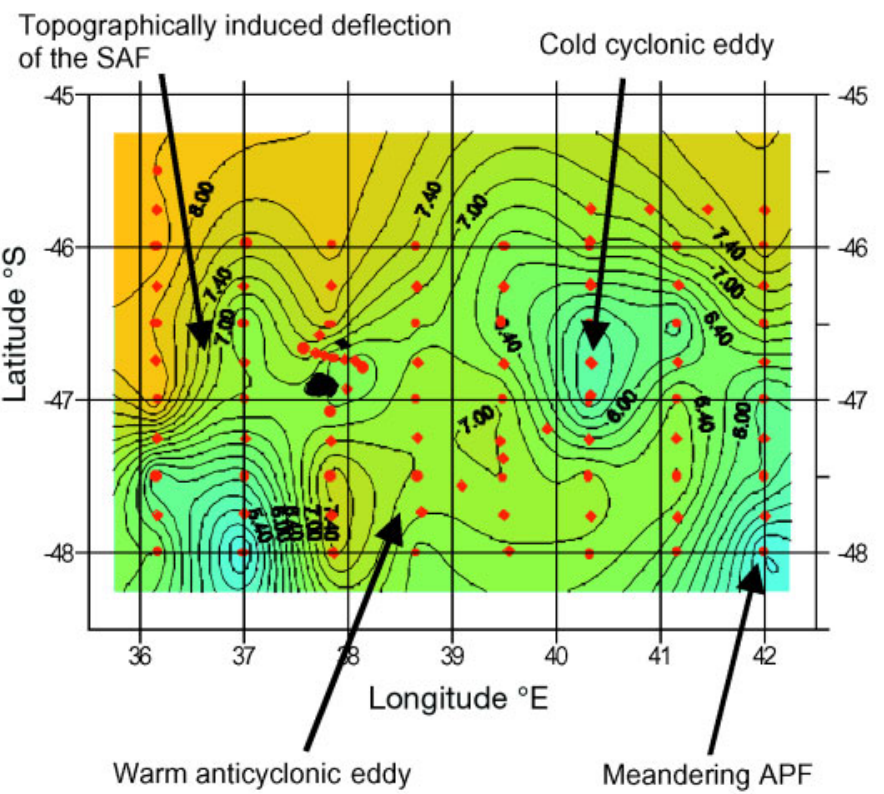

(b) Topex/ERS Sea Surface Height Anomaly

Negative SSHA associated with the cold cyclonic eddy

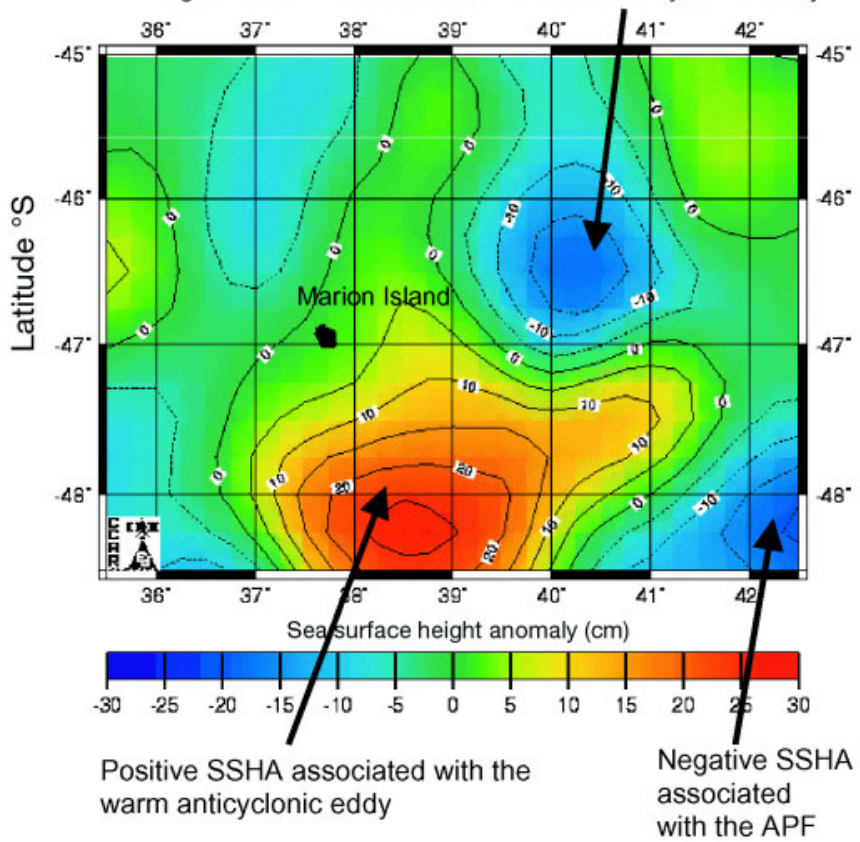

Fig. 1. (a) Sea surface temperature distribution as determined by a hydrographic survey and (b) blended TOPEX/ERS sea surface height anomaly (SSHA) data. Cold cyclonic and warm anticyclonic eddies are clearly visible as positive and negative anomalies in the TOPEX/ERS. APF = Antarctic Polar Front

question, from the point of view of marine organisms, is whether the unusually high variability at this location is due to meandering of the current or to the spawning of eddies. Hydrographic investigation of some of the features originating here and seen in altimetry (I.J.A. \& J.R.E.L. unpubl.) show that they are indeed eddies (Fig. 1) that are created at the ridge and subsequently move towards and past the Prince Edward Islands. It seems that this area at the SouthWest Indian Ridge is the major source of eddies near

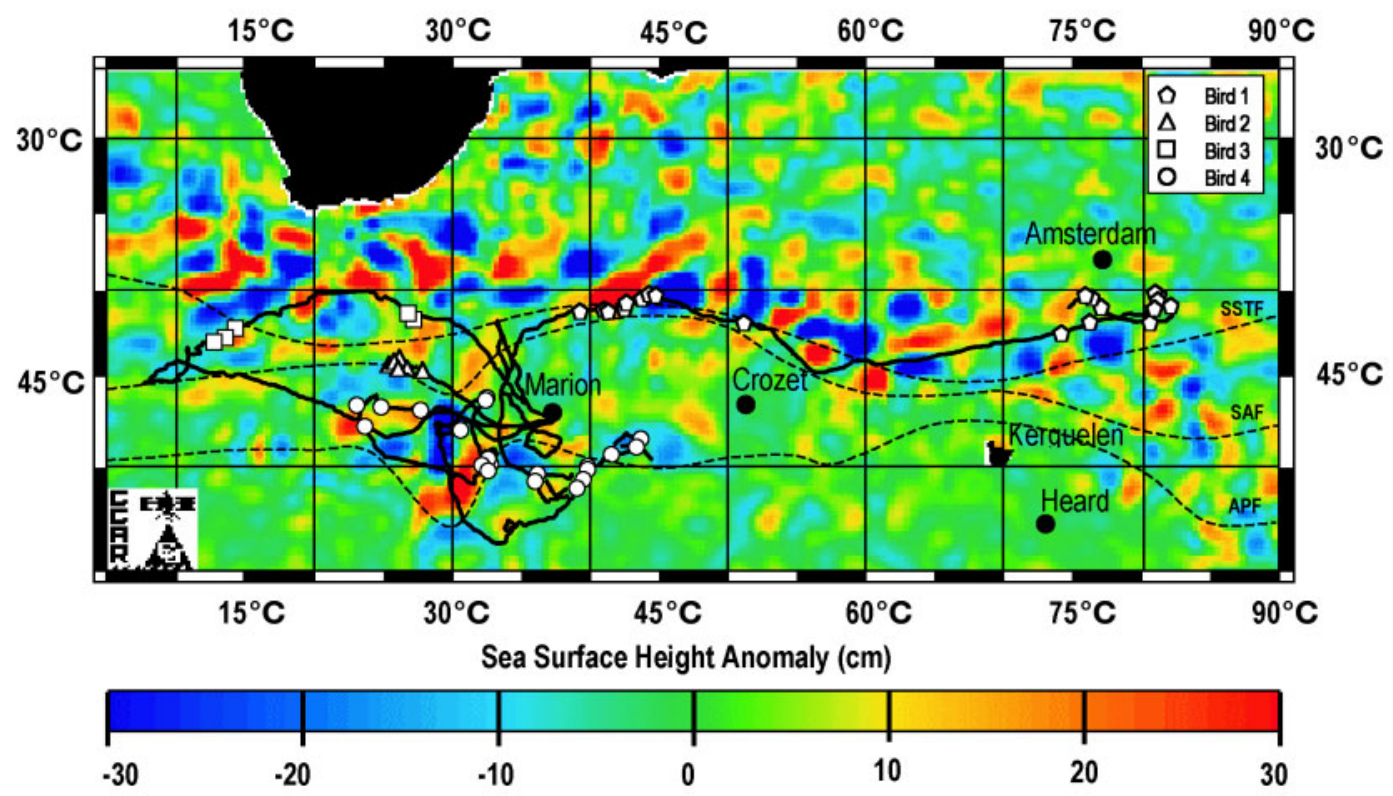

Fig. 2. Foraging tracks of 4 birds tracked from Marion Island by means of PTTs during the incubation stage. Symbols indicate birds moving at $<10 \mathrm{~km} \mathrm{~h}^{-1}$ during the daytime, probably foraging. Dashed lines indicate approximate positions of major fronts (Belkin \& Gordon 1996). SSTF = southern extent of Sub-Tropical Front, SAF = Sub-Antarctic Front, APF = Antarctic Polar Front 
the islands and thus might be of considerable importance to the ecology of the region.

\section{MATERIALS AND METHODS}

Breeding grey-headed albatross were tracked using: (1) ST10 Platform Transmitter Terminals (PTTs), manufactured by Telonics (USA) and packaged by Sirtrack Limited (NZ); and, (2) pillbox Geo-Locating Sensors (GLS) manufactured by Driesen and Kern (DE). The methods by which these devices provide position fixes for the birds are described in Nel et al. (2000). PTTs provided successful locations at $\sim 2 \mathrm{~h}$ intervals, with a normal accuracy of $<5 \mathrm{~km}$, while GLS only give 2 position fixes per $24 \mathrm{~h}$ period, with an accuracy of $\sim 40 \mathrm{~km}$.

The PTTs and GLS weighed $<100 \mathrm{~g}$ and were attached to feathers on the back of the birds (between the wings) by means of adhesive tape. During late incubation (24 November to 17 December 1997) 2 males and 2 females were tracked for a total of $56 \mathrm{~d}$ using PTTs. Birds were captured immediately after they had been relieved of their incubation shift by their mates, and were taken to the side of the colony, where the devices were attached. Attachment took 10 to $15 \mathrm{~min}$. During early chick-rearing (post-brooding, 20 January to 5 February 1998) 3 males and 3 females were tracked for a total of $61 \mathrm{~d}$ and 15 complete foraging trips, using 2 PTTs (on 1 male and 1 female) and 4 GLS (on 2 males and 2 females). Devices were attached to adults immediately after they had completed feeding their chick and were left on for successive foraging trips.

Movement data were plotted and spatially analysed using ARCVIEW GIS Version 3.0a (ESRI, Redlands, CA). All location classes were considered for analysis, unless the location proved to be implausible according to predicted maximum flying speeds by Pennycuik (1982). Distances were calculated using an equidistant azimuthal (south pole) projection. As grey-headed albatross generally forage during the day and rest on the surface during the night (Huin \& Prince 1997), we considered plots of birds moving at $<10 \mathrm{~km} \mathrm{~h}^{-1}$ during daylight hours to be indicative of concentrated foraging in an area. This is consistent with theoretical models that predict that high frequency of prey capture leads to an increase in complexity of movement and decreased velocity in order to maximise search effort in profitable areas (Knoppien \& Reddingius 1985).

Data were analysed in relation to weekly satellite-derived TOPEX sea surface height anomaly data, available from the 'Colorado Centre for Astrodynamics Research' (CCAR) (http://www-ccar.colorado.edu). The TOPEX derived sea surface height anomaly represents a statistical measure of temporal variations in major current systems, caused by either mesoscale eddy activities, such as meandering and eddy shedding, displacement of current axes or fronts, or changing speed and direction of currents (Park \& Gamberoni 1995). Regions of high mesoscale variability correlate closely with either the terminal region of a major western boundary current, such as the Agulhas Current or the Gulf Stream, or where the Antarctic Circumpolar Current interacts with prominent bottom topography, such as in the Drake Passage or at the Crozet-Kerguelen Plateau in the Southern Ocean (Lutjeharms \& Baker 1980). The launch of TOPEX/ POSEIDON in 1992 has resulted in continual mapping of global sea surface topography, from which surface geostrophic currents can be computed. Persistent attempts in the past, using infrared imagery to ascertain the circulation pattern in the Southern Ocean, have been foiled by almost continuous cloud cover. An advantage of using satellite altimetry is its ability to penetrate through cloud cover.

Thirty diet samples were collected from grey-headed albatross chicks between 25 January and 16 April 1998. Chicks were induced to regurgitate by inverting them over a bucket immediately after they had been fed by their parents. No ill effects of this procedure were noticed. Six diet samples were taken from chicks that had been fed by tracked parents. Four of these samples yielded fresh prey items that could be related to a specific tracked foraging trip. These nests were under constant surveillance during the daylight hours and none of these chicks had been fed by the other parent for at least $24 \mathrm{~h}$ prior to sampling. Prey items were judged to be fresh if fresh pieces of the flesh of the item were found in the sample.

Oceanographic fronts follow the descriptions of Belkin \& Gordon (1996), and 'thermal zones' referred to in the text are defined as follows: the Sub-Tropical Frontal Zone (STFZ) is the broader extent of the Sub-Tropical Front (STF); the Sub-Antarctic Zone (SAZ) extends from the Sub-Antarctic Front (SAF) to the southern extent of the STF; and the Polar Frontal Zone (PFZ) extends from the Antarctic Polar Front (APF) to the SAF. See Fig. 2 for the approximate positions of these fronts.

\section{RESULTS}

\section{Foraging movements in relation to physical oceanographic features}

During incubation, 3 of the 4 birds moved north of the island to forage in the vicinity of the STFZ and the SAF (Fig. 2). All 3 of these birds appeared to initially forage at the interface between positive and negative sea surface height anomalies. Bird 1 foraged for $3.2 \mathrm{~d}$ at the edge of a large positive anomaly, situated in the 


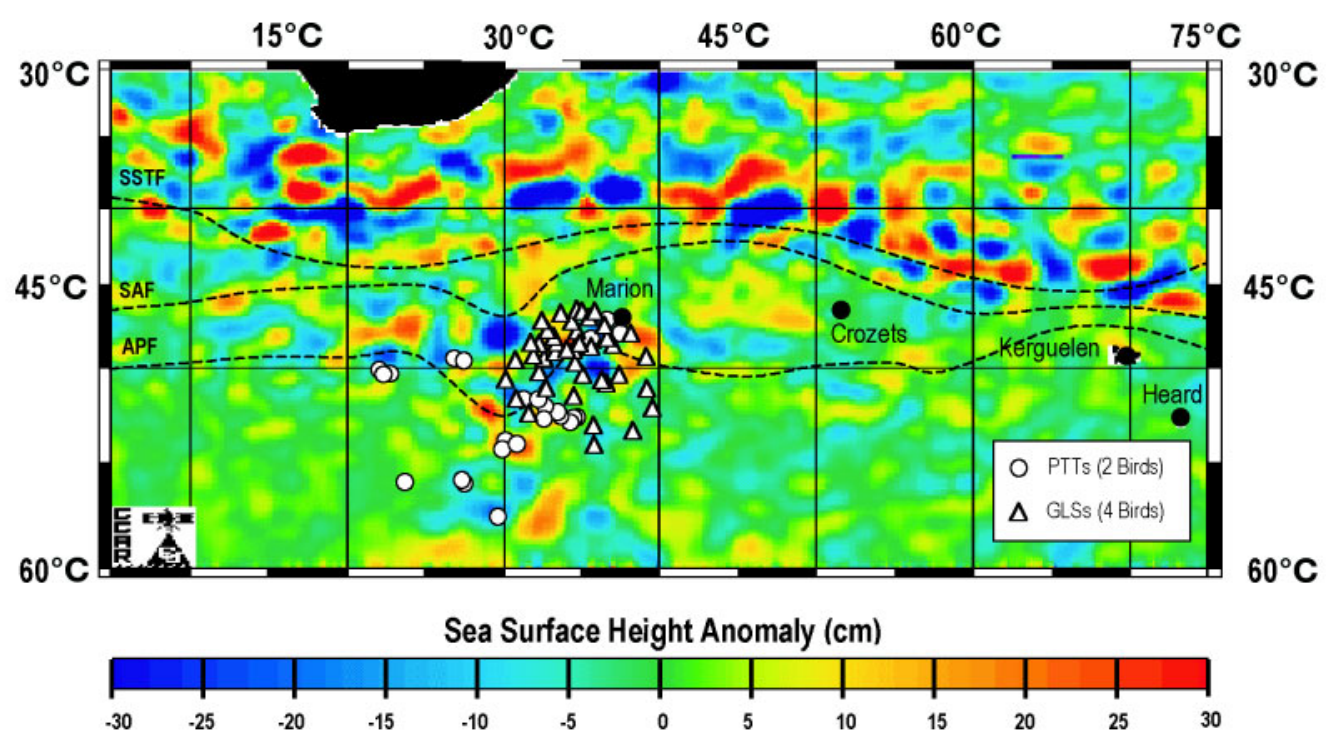

Fig. 3. Foraging distribution of 6 grey-headed albatrosses tracked from Marion Island (by means of 2 PTTs and 4 GLS) during the chick-rearing stage. All GLS positions shown; for PTTs, only positions where birds moving at $<10 \mathrm{~km} \mathrm{~h}^{-1}$ during daylight (probably foraging) are shown. Dashed lines indicate approximate positions of major fronts (Belkin \& Gordon 1996). SSTF = Southern extent of Sub-Tropical Front, SAF = Sub-Antarctic Front, APF = Antarctic Polar Front

STFZ 750 km north of Marion Island, before moving farther east, tracking the string of positive and negative anomalies at the STFZ all the way to Amsterdam Island. Birds 2 and 3 moved northwestwards simulta- neously and foraged around the same positive anomaly within the SAZ, $1000 \mathrm{~km}$ northwest of Marion Island. Unfortunately the device on Bird 2 stopped functioning after it had foraged here for $3.5 \mathrm{~d}$. Bird 3

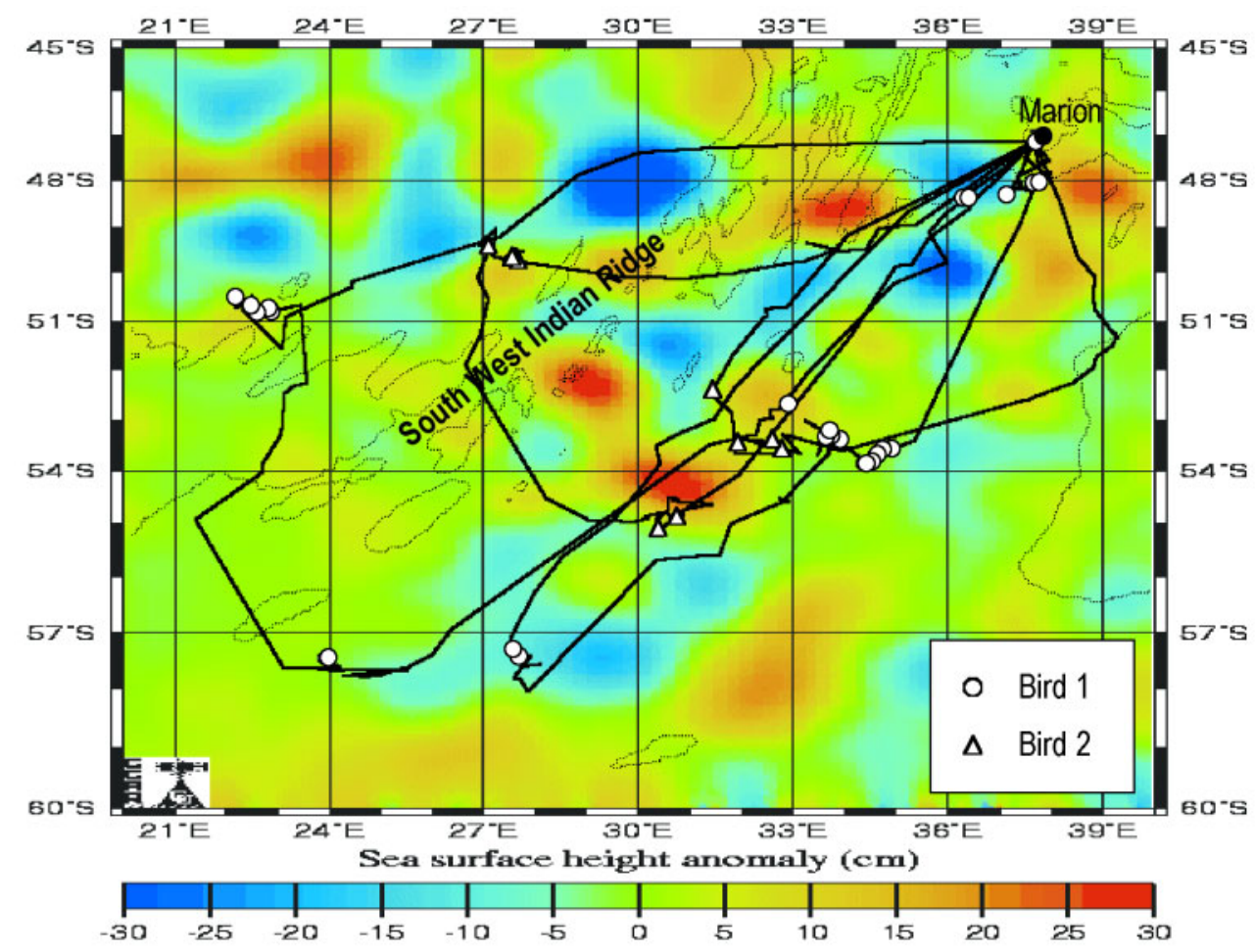

Fig. 4. Foraging tracks from Marion Island, using PTTs during chick-rearing stage. Symbols indicate birds moving $<10 \mathrm{~km}^{-1}$ during daytime, probably foraging. Tracks overlayed onto TOPEX/ERS satellite altimetry image. Dotted lines indicate $4000 \mathrm{~m}$ depth contour 
continued in a westerly arc, passing over the STFZ before moving slightly southwards to forage at the edge of a large negative anomaly in the SAZ. The fourth bird displayed a highly erratic foraging track restricted mostly to the PFZ. However, much of its foraging activity was also concentrated around the edges of positive and negative anomalies.

During small chick-rearing, all 6 tracked birds moved south-west of the island and foraged here on 15 separate foraging trips (Fig. 3). This was despite the large positive anomalies at the STFZ still being well developed. On closer inspection of the fine-scale movements of PTT-tracked foraging trips (Fig. 4), we see that most foraging activity was concentrated on the edges of 2 closely associated positive anomalies at $\sim 52^{\circ}$ to $55^{\circ} \mathrm{S}$ and $30^{\circ}$ to $34^{\circ} \mathrm{E}$ ( 750 to $950 \mathrm{~km}$ away). Both PTTtracked birds foraged in this area on successive foraging trips and both were also present in the area simultaneously. Foraging activity was also recorded at the interface of anomalies located closer to the island (between 100 and $400 \mathrm{~km}$ away). The edge of a positive anomaly just $100 \mathrm{~km}$ south of the island was visited on 3 out of 4 foraging trips made by the same bird. Foraging activity during longer foraging trips was concentrated around negative anomalies south of the APF ( 1300 to $1800 \mathrm{~km}$ away). Most foraging activity was located on either side of the Southwest Indian Ridge. Foraging trips were also very directed during this stage. Birds flew rapidly and directly to an oceanographic feature before slowing down and starting to search for food.

\section{General diet during the chick-rearing period}

Fish (59\%) and cephalopods (32\%) were the major constituents of the solid fraction stomach contents. Crustaceans only contributed $3 \%$ by drained mass. The most common fish species, both by relative abundance and frequency of occurrence was Magnisudis prionosa (Paralepididae), occurring in $30 \%$ of samples (Appendix 1). This was also the largest fish prey item. The smaller myctophids were the second most common family and were represented in $27 \%$ of samples. The most frequently occurring and largest squid prey species was Kondakovia longimana (Appendix 1). However, few of these specimens were fresh and this species was probably over-represented due to large beaks being retained for longer periods in the stomachs of chicks (Berruti \& Harcus 1978). The second most frequently occurring species was the slightly smaller ommastrephid Martialia hyadesi, which was found in $47 \%$ of the samples. $27 \%$ of these specimens were very fresh (i.e. the beak was still attached to the whole squid, the crown of arms, or embedded in the buccal mass). The smaller Chiroteuthis sp. and Histio- teuthis eltaninae both occurred in $33 \%$ of the samples. Chiroteuthis sp. was also the most abundant squid. The cranchiid Galiteuthis glacialis was also represented in $30 \%$ of the samples.

Decapod shrimps were found in $40 \%$ of the samples (Appendix 1). These were mostly Pasiphaea scotia, while 2 larger Austropandalus grayi were also found in 2 separate samples. One complete A. grayi measured $215 \mathrm{~mm}$. Euphausiids were found in $16 \%$ of the samples. All specimens that could be identified to species level were Euphausia superba.

Large numbers of amphipods (mostly Themisto gaudichaudii) were found in $27 \%$ of the samples. Amphipods were also found within the stomach of an unidentified fish.

\section{Diet items associated with particular foraging tracks}

Four diet samples, taken from the chicks of tracked adults yielded fresh prey items. The tracks relating to these samples are shown in Fig. 5. It is simple to associate an oceanographic feature with prey items acquired in Track 1 (Fig. 5a) and Track 3 (Fig. 5c), as these birds only foraged at a single type of feature (i.e. edges of warm eddies located $~ 900$ and $400 \mathrm{~km}$ away respectively). The main prey item of both these foraging trips was the large fish Magnisudis prionosa. Both diet samples also contained fresh specimens of myctophids (Electrona subaspera and Gymnoscopelus piabilis) and the decapod shrimp Pasiphaea scotia. This procedure is slightly more problematic with Track 2 (Fig. 5 b) as this bird foraged at 2 main locations. However, as most foraging time was spent at the edge of a positive anomaly, at the main area of variability $\left(53^{\circ} \mathrm{S}, 33^{\circ} \mathrm{E}\right)$ and this is also the location at which the bird from Track 1 (Fig. 5a) captured 4 specimens of $M$. prionosa at the same time, it is most likely that this is where the specimen of $M$. prionosa in this sample was captured. The specimen of the squid Martialia hyadesi could have been captured at either the warm or the cold core eddy; however, given the frequency of very fresh specimens of this species recorded in our diet samples (Appendix 1), and the fact that Rodhouse et al. (1996) recorded this species in association with warm eddies at the APF in the Scotia Sea, it is most likely that this species was captured at the closer positive anomaly. Euphausia superba only occurs south of the APF (Pakhomov et al. 1994). It is thus most likely that it was this species that was captured at the cold core eddy (farther south). The bird from Track 4 (Fig. 5d) foraged at the edge of the positive anomaly just south of the island ( 100 km away) and captured 5 very fresh specimens of the smaller squid Chiroteuthis sp. A single specimen of $M$. hyadesi was also recovered from this sample. 

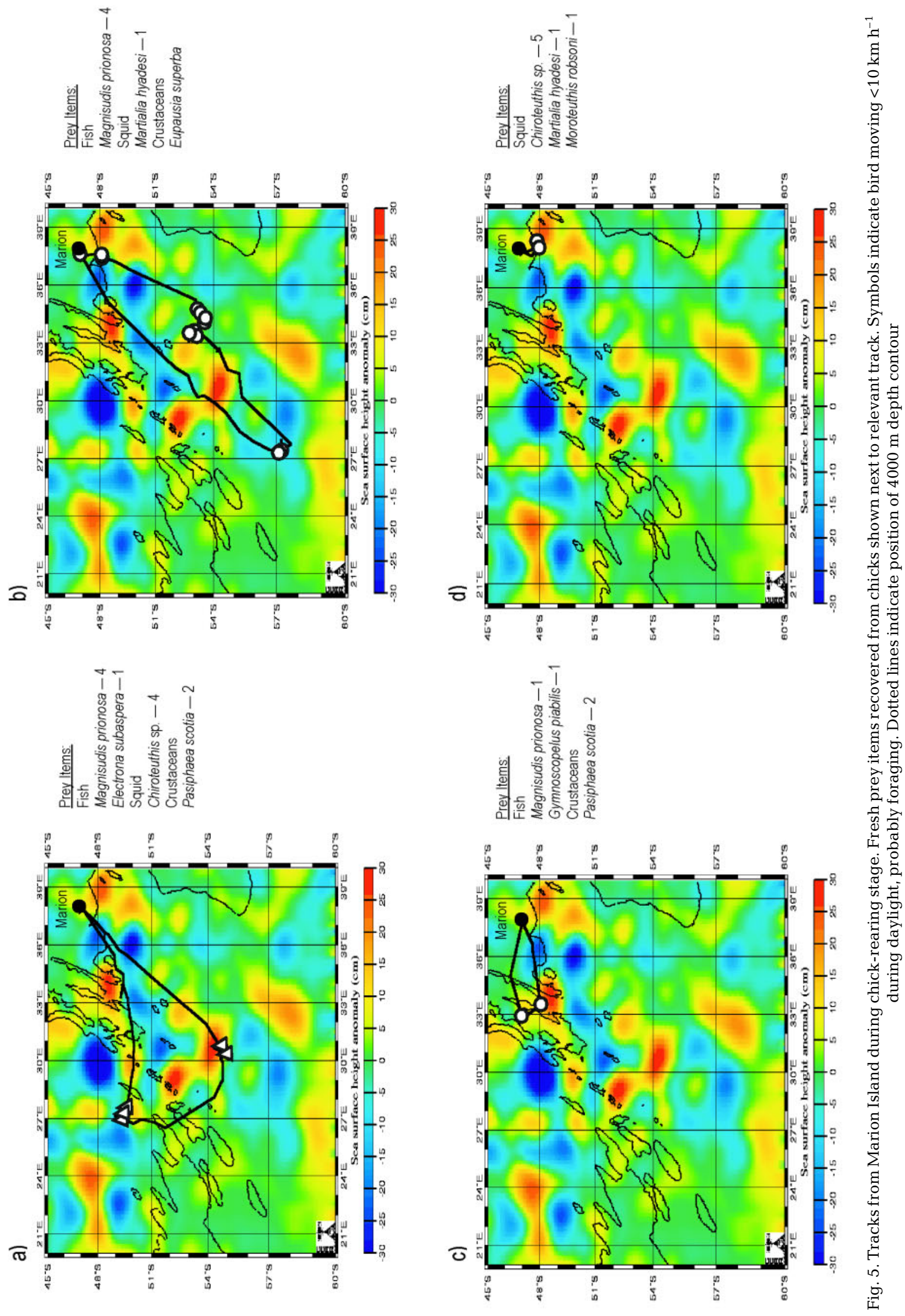


\section{DISCUSSION}

\section{Foraging movements in relation to physical oceanographic features}

Grey-headed albatross tracked from Marion Island showed a strong association with oceanographic features expressed as positive and negative sea surface height anomalies, both during the incubation and chickrearing stages. Interestingly, most foraging activity was concentrated at the edges of these anomalies or at the interface between positive and negative anomalies. During incubation, most birds preferred to exploit oceanographic features to the north of the island, in the STFZ and the SAZ. We cannot say unequivocally that these features, as seen in the altimetry, are eddies, but the results of previous hydrographic research in the region (e.g. Lutjeharms \& Valentine 1988, Lutjeharms 1990) gives us confidence that this is the case. These features are formed largely as a result of the interaction between the Agulhas Return Current and bathymetric features such as the Madagascar Ridge (Pollard \& Read 2001).

By contrast, during chick-rearing no foraging trips were made to the STFZ, despite oceanographic features still being well developed here, but were instead made exclusively to the southwest of the island. Most foraging activity occurred at the edges of altimetric features located to the south-west of the island and either side of the South-West Indian Ridge. A number of such mesoscale features have been investigated hydrographically (Ansorge et al. unpubl. ms.) and in all cases it has been shown that they are eddies. This area, to the leeward side of the South-West Indian Ridge was also used extensively by elephant seals Mirounga leonine tracked from Marion Island (Jonker \& Bester 1998). Grey-headed albatross breeding on South Georgia have also been shown to forage at warm eddies in the PFZ, which occur predictably due to bathymetric features (Rodhouse et al. 1996). It is worth noting that although many of the eddies occurring on the South-West Indian Ridge, both cyclonic and anti-cyclonic, have been shown to eventually drift by the Prince Edward Islands (Ansorge et al. 2000), the birds preferred to utilize recently formed eddies. This suggests that the biological content of these eddies may change with time and/or that eddies located closer to the island experience higher levels of competition and local depletion by the large populations of non-aerial and less mobile predators (i.e. fur seals and penguins) breeding on Marion Island (see discussion of diets in next section).

There thus appear to be 2 areas of high variability within the foraging range of grey-headed albatross: (1) the STFZ to the north of the island, and (2) the area where the ACC crosses the South-West Indian Ridge to the south west of the island. These 2 areas are at a similar distance from the island, and positive and negative anomalies were present in these areas during both the incubation and chick-rearing stages (Figs 2 \& 3). It is thus unclear why birds would switch to foraging exclusively to the south of the island during chick-rearing. The most plausible explanation is that, although the main area of variability to the southwest of the island occurs at 700 to $900 \mathrm{~km}$ from the island, eddies appear to persist closer to the island as well (Fig. 4, Ansorge et al. 2000). Weimerskirch (1999) showed that shorter foraging trips for albatross were aimed primarily at meeting the energetic demands of the chick, while longer foraging trips resulted in the adult regaining its body condition. Foraging to the south of the island along the South-West Indian Ridge gives the adults a choice of several warm and cold eddies at a range of distances from the island and state of degradation or local depletion by less mobile predators. The selected foraging area will be a compromise between the energetic needs of the chick and the body condition of the parent. During incubation birds are away from the island for far longer periods (Nel et al. 2000) and are not under the constraint of needing to return to their breeding locality in order to feed a chick at regular intervals. This allows adults to forage further from the island and be more selective about their foraging area.

\section{General diet during chick rearing}

Diet samples, taken from a larger sample of birds ( $\mathrm{n}=30$ ) during the chick-rearing period revealed a predominance of species associated with the SAZ and PFZ, thus confirming that the adults were foraging exclusively to the south of the island during this period. Little is known about the biology and distribution of the most frequently occurring fish species, Magnisudis prionosa (Gon \& Heemstra 1990), although it has been recorded in the diets of grey-headed and blackbrowed albatross Thalassarche melanophrys at South Georgia (Reid et al. 1996), as well as in the diets of several other sub-Antarctic species known to feed mainly in the PFZ, including king penguins Aptenodytes patagonicus (Hindell 1988), Antarctic fur seals Arctocephalus gazella and Subantarctic fur seals Arctocephalus tropicalis (Green et al. 1990, Klages \& Bester 1998). Four of the 6 myctophids found in our samples (Electrona antarctica, Electrona carlsbergi, Gymnoscopelus bolini, Krefftichthys andersoni) only occur in the upper water column at or south of the APF (Gon \& Heemstra 1990). To date, little is known about the fish stocks in the SAZ and PFZ. The limited number of acoustic and trawling surveys conducted in the Atlantic sector of the Southern Ocean indicate that 
during the austral summer high myctophid stocks are associated with the APF and southern parts of the PFZ (Filin et al. 1991, Pakhomov et al. 1994, 1996).

The most frequently occurring fresh prey item, the ommastrephid squid Martialia hyadesi, is strongly associated with the APF (Rodhouse et al. 1992) and has also been found to associate with warm eddies that form at the APF in the Scotia Sea (Rodhouse et al. 1996). This species has major potential for commercial exploitation (Rodhouse 1997). M. hyadesi is a major squid prey of the mollymawk albatross species (genus Thalassarche) breeding across the entire Southern Ocean (Rodhouse et al. 1990, Ridoux 1994, Waugh et al. 1999). Knowledge of the environmental variables that influence its abundance and distribution are therefore of utmost importance.

\section{Prey items associated with particular oceanographic features}

The data suggest that birds were feeding at the edges of sea surface height anomalies mostly on larger predators (e.g. the fish Magnisudis prionosa and the squid Martialia hyadesi), which are presumably attracted by the presence of potential prey such as myctophids and crustaceans (e.g. decapod shrimps). These in turn could have been attracted by elevated stocks of copepods, amphipods (particularly Themisto gaudichaudii) and euphausiids, which were also well represented in our samples. Small amphipods (mainly $T$. gaudichaudii) and euphausiids are the most consistent components in the diet of adult Antarctic myctophids (Koslov \& Tarverdieva 1989). Furthermore, amphipods were found in a stomach of an unidentified fish in one of our albatross diet samples. Although this is a single opportunistic record, it confirms the structure of the food chain suggested above. Continuous acoustic measurements in this region clearly indicated that the biomass of large plankton and micronekton (>20 $\mathrm{mm}$ in length) was consistently elevated at both warm and cold eddies (Pakhomov \& Froneman 2000). Although the acoustic data do not discriminate species, these findings provide first evidence that positive and negative sea surface height anomalies (sensu warm and cold eddies) might contain elevated stocks of potential prey for epipelagic fish and squid, which in turn are preyed upon by grey-headed albatross. Rodhouse et al. (1996) reported that grey-headed albatross tracked from South Georgia while exploiting warm eddies at the PFZ fed mainly on the squid M. hyadesi. Sampling in these areas using pelagic trawls revealed that these squid were feeding mainly on myctophids, which presumably become concentrated by warm eddies. Myctophids, euphausiids and amphipods, especially $T$. gaudichaudii, are also the major prey items of the squid $M$. hyadesi at the APF in the Scotia Sea (Rodhouse et al. 1992). Rodhouse \& White (1995) demonstrated that in the Scotia Sea the dominant predators in the epipelagic system at the PFZ were squid. Our data suggest that a predatory fish, M. prionosa, may also be an important member of the epipelagic predator community at the PFZ in the Southern Indian Ocean.

Exactly how positive and negative sea surface height anomalies (sensu warm and cold eddies) concentrate prey near the surface is unknown at the moment. However, Wiebe (1982) demonstrated that slope-water euphasiids move downwards in decaying cold eddies in an attempt to stay in their preferred environment. It is thus possible that crustaceans might be forced to move upwards in decaying warm eddies in order to stay in their preferred environment. This would make them accessible to epipelagic predators and initiate a trophic chain ending with top predators breeding on the Prince Edward Islands. It has recently been demonstrated that eddies spawned off the major frontal systems are rich in zooplankton/micronekton standing stock (Craddock et al. 1992, Wiebe \& Youce 1992, Pakhomov et al. 1994, Pakhomov \& Perissinotto 1997). The eddies may persist for up to 6 mo (Lutjeharms \& Gordon 1987, Lutjeharms \& Valentine 1988) and exhibited elevated primary productivity at the edges (Dower \& Lucas 1993, Froneman et al. 1999). Eddies are therefore regarded as important vehicles in transporting unique or dense zooplankton communities, providing ideal feeding grounds for top predators (Sugimoto \& Tameishi 1992, Barange et al. 1998). However, physical mechanisms and trophic links within eddies are as yet poorly understood and will be the subject of future research in the region southwest of the Prince Edward Islands.

The data presented in this paper provide the first insights into the nature and importance of these physical oceanographic features to top predators in this region. The findings of this study further demonstrate that productive eddies occurred at a range of distances from the island. Eddies that occur closer to the island could also be important for non-aerial predators breeding on Marion Island (i.e. penguins and seals). These species are not able to cover the vast distances covered by albatross, but are able to exploit resources occurring further down in the water column. Myctophids, which become concentrated at warm eddies (Rodhouse et al. 1996), dominate the diets of both King Penguins and fur seals at Marion Island (Adams \& Klages 1987, Klages \& Bester 1998). Furthermore, king penguins tracked from nearby Crozet Island showed that breeding birds made long directed foraging trips (indicative of a predictable food resource) to the PFZ 
(Jouventin et al. 1994). Finally, elephant seals tracked from Marion Island also showed intensive foraging activity on the leeward side of the Southwest Indian ridge. We therefore suggest that this area of high mesoscale eddy activity, created by the ACC crossing the South-West Indian Ridge, could be an important component of the 'life-support system' for numerous globally significant populations of seabirds and seals breeding on Marion Island.
Acknowledgements. Financial and logistical support was received from the Department of Environmental Affairs and Tourism through the South African National Antarctic Programme, the Foundation for Research and Development, the Charl van der Merwe Foundation, and the University of Cape Town. PTTs were kindly supplied by Graham Robertson of the Australian Antarctic Division, while the World Wide Fund for Nature (WWF) covered the satellite link-up costs. Many thanks also to Rory Wilson, Institut für Meereskunde, who kindly supplied the GLS and also computed the locations from the raw data.

Appendix 1. Relative abundance, frequency of occurrence and estimated lengths and masses of prey items identified in diet samples collected during chick-rearing period at Marion Island, 1998. Unid.: unidentified

\begin{tabular}{|c|c|c|c|c|c|c|c|}
\hline \multirow[t]{2}{*}{ Taxa } & \multirow{2}{*}{$\begin{array}{l}\text { Relative } \\
\text { abundance }\end{array}$} & \multirow{2}{*}{$\begin{array}{l}\text { Frequency of } \\
\text { occurrence } \\
\text { (Total) (\%) }\end{array}$} & \multirow{2}{*}{$\begin{array}{l}\text { Frequency of } \\
\text { occurrence } \\
\text { (Fresh) (\%) }\end{array}$} & \multicolumn{2}{|c|}{$\begin{array}{c}\text { Estimated length }(\mathrm{mm}) \\
(\text { Fish }=\mathrm{TL}, \text { Squid }=\mathrm{ML}, \text { Crus }=\mathrm{CL})\end{array}$} & \multicolumn{2}{|c|}{ Estimated mass (g) } \\
\hline & & & & Mean & Range & Mean & Range \\
\hline FISH & 75 & 90 & 63 & & & & \\
\hline Family Macrouridae & 2 & 3 & 3 & & & & \\
\hline Cynomacrurus piriei & 1 & 3 & 3 & & & & \\
\hline Unid. Macrouridae & 1 & 3 & & & & & \\
\hline Family Myctopidae & 14 & 27 & 10 & & & & \\
\hline Electrona antarctica & 4 & 3 & & $103.8 \pm 38.2$ & $70.7-136.9$ & $20.5 \pm 18.2$ & $4.7-36.2$ \\
\hline Electrona carlsbergi & 1 & 3 & & 58.2 & & 3.58 & \\
\hline Electrona subaspera & 1 & 3 & 3 & 92.5 & & 14.9 & \\
\hline Gymnoscopelus bolini & 2 & 3 & & & & & \\
\hline Gymnoscopelus piabilis & 1 & 3 & 3 & 167.9 & & 99.9 & \\
\hline Gymnoscopelus sp. & 1 & 3 & & & & & \\
\hline Krefftichthys andersoni & 3 & 7 & & $44.5 \pm 2.4$ & $41.7-45.9$ & $0.878 \pm 0.14$ & $0.71-0.96$ \\
\hline Unid. Myctophidae & 1 & 3 & 3 & 52 & & & \\
\hline Family Paralepididae & & & & & & & \\
\hline Magnisudis prionosa & 39 & 30 & 20 & $452.5 \pm 68.6$ & $198.2-624.4$ & $321.6 \pm 48.7$ & $140.9-443.7$ \\
\hline Family Photichthydae & & & & & & & \\
\hline Photichthys argenteus & 2 & 7 & 7 & 309.5 & & 126.3 & \\
\hline Unid. Fish & 18 & 53 & 33 & $324.4 \pm 76.3$ & $270-378$ & & \\
\hline SQUID & 315 & 97 & 68 & & & & \\
\hline Family Chiroteuthidae & & & & & & & \\
\hline Chiroteuthis sp. & 66 & 33 & 7 & $111.4 \pm 10.7$ & $82.3-150.8$ & $36.1 \pm 10.4$ & $13.9-86.3$ \\
\hline Family Cranchiidae & & & & & & & \\
\hline Galiteuthis glacialis & 65 & 30 & & $219 \pm 13.5$ & $187.6-248.7$ & $93.2 \pm 14.3$ & $62.9-126.6$ \\
\hline Family Gonatidae & & & & & & & \\
\hline Gonatus antarcticus & 8 & 20 & & $290.4 \pm 12.1$ & $270.6-304.9$ & $178.6 \pm 28.6$ & $134.1-214.1$ \\
\hline Family Histioteuthidae & & & & & & & \\
\hline Histioteuthis eltaninae & 14 & 33 & 3 & $62.2 \pm 11.1$ & $44.1-90.8$ & $86.5 \pm 31.0$ & $44.8-175.7$ \\
\hline Family Mastigoteuthidae & & & & & & & \\
\hline Mastigoteuthis psychrophila & ila & 7 & & $164.9 \pm 41.4$ & $117.4-193.0$ & $203.3 \pm 116.8$ & $69.9-287.7$ \\
\hline $\begin{array}{l}\text { Family Neoteuthidae } \\
\text { Alluroteuthis antarctica }\end{array}$ & 14 & 30 & 3 & $147.1 \pm 31.6$ & $70.4-202.0$ & $389.5 \pm 210.5$ & $38-898.9$ \\
\hline Family Ommastrephidae & & & & & & & \\
\hline Martialia hyadesi & 46 & 47 & 27 & $233.3 \pm 35.5$ & $150-287.7$ & $227.5 \pm 105.9$ & $60.9-445.6$ \\
\hline Family Onychoteuthidae & 61 & 60 & 10 & & & & \\
\hline Konakovia longimana & 47 & 53 & 10 & $387.8 \pm 110.7$ & $149.3-533.7$ & $1648 \pm 957.3$ & $87.5-3556.1$ \\
\hline Moroteuthis ingens & 1 & 3 & & 600.4 & & 2625.6 & \\
\hline Moroteuthis robsoni & 3 & 7 & & $309.1 \pm 26.5$ & $284.5-337.1$ & $766.3 \pm 104.0$ & $671.8-877.6$ \\
\hline Family Psychroteuthidae & & & & & & & \\
\hline Psychroteuthis glacialis & 1 & 3 & & 26.2 & & 90.9 & \\
\hline Unid. squid & 47 & 43 & & & & & \\
\hline CRUSTACEANS & 174 & 70 & 70 & & & & \\
\hline Amphipoda & 116 & 27 & 27 & & & & \\
\hline Themisto guadichaudii & 114 & 20 & 20 & & & & \\
\hline Unidentified amphipods & 2 & 7 & 7 & $29.5 \pm 4.9$ & $26-33$ & & \\
\hline Decapoda & 18 & 40 & 40 & & & & \\
\hline Austopandalus grayi & 2 & 7 & 7 & $69.5 \pm 7.8$ & $64.0-75.0$ & & \\
\hline Pasiphaea scotia & 10 & 23 & 23 & $33.3 \pm 6.3$ & $24.0-40.0$ & & \\
\hline Unidentified decapods & 6 & 9 & 9 & & & & \\
\hline Euphausiacea & 36 & 17 & 17 & & & & \\
\hline Euphausia superba & 4 & 3 & 3 & & & & \\
\hline Unid. euphausiids & 32 & 13 & 13 & & & & \\
\hline Isopoda & & & & & & & \\
\hline Unid. Isopods & 4 & 13 & & & & & \\
\hline OTHER & 10 & 20 & 7 & & & & \\
\hline Goose barnacles & 4 & 3 & 3 & & & & \\
\hline Penguin feathers & 3 & 10 & & & & & \\
\hline Jelly fish & 2 & 7 & 7 & & & & \\
\hline Mammal lung and stomach & 1 & 3 & 3 & & & & \\
\hline
\end{tabular}




\section{LITERATURE CITED}

Abrams RW (1983) Distribution of seabirds in the African sector of FIBEX. S Afr J Antarc Res 13:24-28

Abrams RW (1985a) Energy and food requirements of pelagic aerial seabirds in different regions of the African sector of the Southern Ocean. In: Siegfried WR, Condy PR, Laws RM (eds) Antarctic nutrient cycles and food webs. Springer, Heidelberg, p 466-472

Abrams RW (1985b) Environmental determinants of pelagic seabird distribution in the African sector of the Southern Ocean. J Biogeogr 12:473-492

Abrams RW, Lutjeharms JRE (1986) Relationship between seabirds and meso-scale hydrographic features in the Agulhas Current retroflection region. In: Acta XIX Congressus Internationalis Ornithologici, Ottawa, Canada, 22-29 June 1986, Vol 1, p 991-996

Abrams RW, Miller DGM (1986) The distributions of pelagic seabirds in relation to the oceanic environment of Gough Island. S Afr J Mar Sci 4:125-137

Adams NJ, Klages NTW (1987) Seasonal variation in the diet of the king penguin (Aptenodytes patagonicus) at subAntarctic Marion Island. J Zool Lond 212:303-324

Allanson BR, Hart RC, Lutjeharms JRE (1981) Observations on the nutrients, chlorophyll and primary production of the Southern Ocean south of Africa. S Afr J Antarc Res 10:3-14

Anderson DJ, Ricklefs RE (1987) Radio-tracking masked and blue-footed boobies (Sula spp.) in the Galapagos Islands. Natl Geogr Res 3:152-163

Ansorge IJ, Froneman PW, Pakhomov EA, Lutjeharms JRE, Perissinotto R, van Ballegooyen RC (1999) Physical-biological coupling in the waters surrounding the Prince Edward Islands (Southern Ocean). Polar Biol 21: 135-145

Ashmole NP (1971) Seabird ecology and the marine environment. In: Farner DS, King JR (eds) Avian biology, Vol 1, Academic Press, New York

Barange M, Pakhomov EA, Perissinotto R, Froneman PW, Verheye HM, Taunton-Clark J, Lucas MI (1998) Pelagic community structure of the Subtropical Convergence region south of Africa and in the mid-Atlantic Ocean. Deep-Sea Res 45:1663-1687

Belkin IM, Gordon AL (1996) Southern Ocean fronts from the Greenwich meridian to Tasmania. J Geophys Res 101: 3675-3696

Berruti A, Harcus T (1978) Cephalopod prey of the sooty albatrosses Phoebetria fusca and P. palpebrata at Marion Island. S Afr J Antarct Res 8:99-103

Boden BP, Duncombe Rae CM, Lutjeharms JRE (1988) The distribution of the diatoms of the south-west Indian Ocean surface waters between Cape Town and the Prince Edward Island archipelago. S Afr J Sci 84:811-818

Chenney RE, Marsh JG, Beckley BD (1983) Global mesoscale variability from collinear tracks of Seasat altimeter data. J Geophys Res 88:4343-4354

Cherel Y, Klages NTW (1997) A review of the food of albatrosses (Diomedeidae). In: Robertson G, Gales R (eds) Albatross biology and conservation. Surrey Beatty \& Sons, Chipping Norton, p 113-136

Cherel Y, Weimerskirch H (1995) Seabirds as indicators of marine resources: black-browed albatrosses feeding on ommastrephid squids in Kerguelen waters. Mar Ecol Prog Ser 129:295-300

Clarke MR (1986) A handbook for the identification of cephalopod beaks. Oxford University Press, Oxford

Colton MT, Chase RRP (1983) Interaction of the Antarctic cir- cumpolar current with bottom topography - an investigation using satellite altimetry. J Geophys Res 88:1825-1843

Craddock JE, Backus RH, Daher MA (1992) Vertical distribution and species composition of midwater fishes in warmcore Gulf Stream meander/ring 82-H. Deep-Sea Res 39: $203-218$

Daniault N, Menard Y (1985) Eddy kinetic energy distribution in the Southern Ocean from altimetry and FGGE drifting buoys. J Geophys Res 90:1187-1189

Dower KM, Lucas M (1993) Photosynthesis-irradiance relationships and production associated with a warm-core ring shed from the Agulhas Retroflection south of Africa. Mar Ecol Prog Ser 95:141-154

Filin AA, Gorchisky KV, Kiseleva VM (1991) Biomass of myctophidsin the Atlantic sector of the Southern Ocean as estimated by acoustic surveys. Selected Scientific Papers (SC-CAMLR-SSP/7). CCAMLR, Hobart, p 417-431

Froneman PW, Ansorge IJ, Pakhomov EA, Lutjeharms JRE (1999a) Plankton community structure in the physical environment surrounding the Prince Edward Islands (Southern Ocean). Polar Biol 22:145-155

Froneman PW, McQuaid CD, Laubscher RK (1999b) Sizefractionated primary production studies in the vicinity of the Subtropical Front and an adjacent warm-core eddy south of Africa in austral winter. J Plankton Res 21: 2019-2035

Gon O, Heemstra PC (1990) Fishes of the Southern Ocean. JLB Institute, Grahamstown

Green K, Williams R, Handasyde K, Burton HR, Shaugnessy PD (1990) Interspecific and intra-specific differences in the diets of three species of Arctocephalus (Pinnepedia: Otariidae) at Macquarie Island. Aust Mamm 13:193-200

Haney JC, Haury LR, Mullineaux LS, Fey CL (1995) Sea-bird aggregation at a deep North Pacific seamount. Mar Biol 123:1-9

Hindell MA (1988) The diet of king penguins Aptenodytes patagonicus at Macquarie Island. Ibis 130:193-203

Huin N, Prince PA (1997) Diving behaviour of the greyheaded albatross. Antarct Sci 9:243-249

Hunt GL, Mehlum F, Russel RW, Irons D, Decker MB, Becker PH (1999) Physical processes, prey abundance and the foraging ecology of seabirds. In: Adams NJ, Slotow RH (eds) Proc 22nd Int Ornithol Congr, Durban, 16-22 August 1998. Birdlife South Africa, Johannesburg, p 2040-2056

Jouventin P, Capdeville D, Cuenot-Chaillet F, Boiteau C (1994) Exploitation of pelagic resources by a non-flying seabird: satellite tracking of the king penguin throughout the breeding cycle. Mar Ecol Prog Ser 106:11-19

Jonker FC, Bester MN (1998) Seasonal movements and foraging areas of adult southern elephant seals, Mirounga Leona, from Marion Island. Antarct Sci 10:21-30

Klages NTW, Bester MN (1998) Fish prey of fur seals Arctocephalus spp. at Subantarctic Marion Island. Mar Biol 131: 559-566

Kozlov AN, Tarverdieva MN (1989) Feeding of different species of Myctopydae in different parts of the Southern Ocean. J Ichthyol 29:160-167

Knoppien P, Reddingius J (1985) Predators with two modes of searching: a mathematical model. J Theor Biol 114: 273-301

Lack D (1968) Ecological adaptations for breeding birds. Menthuen, London

Lutjeharms JRE (1990) Temperatuurstruktuur van die oseaanbolaag tussen Kaapstad en Marion-eiland. S Afr J Antarct Res 20:21-32

Lutjeharms JRE, Ansorge IJ (in press) The agulhas return current. J Mar Syst 
Lutjeharms JRE, Baker DJ (1980) A statistical analysis of the meso-scale dynamics of the Southern Ocean. Deep-Sea Res 27:145-159

Lutjeharms JRE, Walters NM, Allanson BR (1985) Oceanic frontal systems and biological enhancement. In: Siegfried WR, Condy PR, Laws RM (eds) Antarctic nutrient cycles and food webs. Springer-Verlag, Heidelberg, p 11-21

Lutjeharms JRE, Allanson BR, Parker L (1986) Frontal zones, chlorophyll and primary production patterns in the surface waters of the Southern Ocean south of Africa. In: Nihoul JCJ (ed) Marine interfaces ecohydrodynamics, Elsevier Oceanography Series, Proceedings of the 17th International Liege Colloquium, p 105-117

Lutjeharms JRE, Gordon AL (1987) Shedding of an Agulhas ring observed at sea. Nature 325:138-140

Lutjeharms JRE, Valentine HR (1984) Southern Ocean thermal fronts south of Africa. Deep-Sea Res 31:1461-1476

Lutjeharms JRE, Valentine HR (1988) Eddies at the subtropical convergence south of Africa. J Phys Oceanogr 18:761-774

Nel DC, Nel JL, Klages NTW, Wilson RP, Robertson G (2000) The foraging ecology of grey-headed mollymawks at Marion Island, Southern Indian Ocean, in relation to known longline fishing activity. Biol Conserv 96:219-231

Nevitt G (1999) Olfactory foraging in Antarctic seabirds: a species-specific attraction to krill odors. Mar Ecol Prog Ser 79:243-258

Machu E, Ferret B, Garço V (1999) Phytoplankton pigment distribution from SeaWiFS data in the subtropical convergence zone south of Africa: a wavelet analysis. Geophys Res Lett 26:1469-1472

Pakhomov EA, Froneman PW (2000) Composition and spatial variability of macroplankton and micronekton within the Antarctic Polar Frontal Zone of the Indian Ocean during austral autumn 1997. Polar Biol 23:410-419

Pakhomov EA, McQuaid CD (1996) Distribution of surface zooplankton and seabirds across the Southern Ocean. Polar Biol 16:271-286

Pakhomov EA, Perissinotto R (1997) Mesozooplankton communoity structure and grazing impact in the region of the Subtropical Convergence south of Africa. J Plankton Res 19:675-691

Pakhomov EA, Perissinotto R, McQuaid CD (1994) Comparitive structure of the macro-zooplankton/micronekton communities of the subtropical and Antarctic polar fronts. Mar Ecol Prog Ser 111:155-169

Pakhomov EA, Perissinotto R, McQuiad CD (1996) Prey composition and daily rations of myctophid fishes in the Southern Ocean. Mar Ecol Prog Ser 134:1-14

Park YH, Gamberoni E (1995). Large-scale circulation and its variability in the South Indian Ocean from TOPEX/ POSEIDON altimetry. J Geophys Res 100:24911-24929

Pennycuik CJ (1982) The flight of pertrels and albatrosses (Procellariformes) observed on South Georgia and its vicinity. Philos Trans R Soc Lond B Biol Sci 300:75-106

Perissinotto R, Duncombe Rae CM (1990) Occurrence of anticyclonic eddies on the Prince Edward Plateau (Southern Ocean): effects on phytoplankton biomass and production. Deep-Sea Res 37:777-793

Perissinotto R, Lutjeharms JRE, van Ballegooyen RC (2000) Biological-physical interactions and pelagic productivity at the Prince Edward Islands, Southern Ocean. J Mar Syst 24:327-341

Piontkovski SA, Williams R, Malnik TA (1995) Spatial heterogeneity, biomass and size structure of plankton of the

Editorial responsibility: Otto Kinne (Editor)

Oldendorf/Luhe, Germany
Indian Ocean: some general trends. Mar Ecol Prog Ser 117:219-227

Pollard RT, Read JF (2001) Circulation pathways and transports of the Southern Ocean in the vicinity of the Southwest Indian Ridge. J Geophys Res 106:2881-2898

Read JF, Pollard RT (1993) Structure and transport of the Antarctic Circumpolar Current and Agulhas Return Current at $40^{\circ} \mathrm{E}$. J Geophys Res 98:12281-12295

Reid K, Croxall JP, Prince PA (1996) The fish diet of blackbrowed albatross Diomedea melanophris and greyheaded albatross D. chrysostoma at South Georgia. Polar Biol 16:469-477

Ricklefs RE (1990) Seabird life histories and the marine environment: some speculations. Colon Waterbirds 13:1-79

Ridoux V (1994) The diets and dietary segregation of seabirds at the Subantarctic Crozet Islands. Mar Ornithol 22: $1-92$

Rodhouse PG (1997) Precautionary measures for a new fishery on Martialia hyadesi (Cephalopoda, Ommastrephidae) in the Scotia Sea: an ecological approach. CCAMLR Sci 4:125-139

Rodhouse PG, White MG (1995) Cephalopods occupy the ecological niche of epipelagic fish at the Antarctic Polar Frontal Zone. Biol Bull 189:77-80

Rodhouse PG, Prince PA, Clarke MR, Murray AWA (1990) Cephalopod prey of the grey-headed albatross Diomedea chrysostoma. Mar Biol 104:353-362

Rodhouse PG, White MG, Jones MRR (1992) Trophic relations of the cephalopod Martialia hyadesi (Teuthoidea: Ommastrephidae) at the Antarctic Polar Front, Scotia Sea. Mar Biol 114:415-421

Rodhouse PG, Prince PA, Trathan PN, Hatfield EMC, Watkins JL, Bone DG, Murphy EJ, White MG (1996) Cephalopods and mesoscale oceanography at the Antarctic Polar Front: satellite tracked predators locate pelagic trophic interactions. Mar Ecol Prog Ser 136:37-50

Snaith HM, Robinson IS (1996) A study of currents south of Africa using Geosat satellite altimetry. J Geophys Res 101:18141-18154

Sugimoto T, Tameishi H (1992) Warm-core rings, streamers and their role on the fishing ground formation around Japan. Deep-Sea Res 39:183-201

Wakker KF, Zandbergen RCA, Naeije MC, Ambrosius BAC (1990) Geosat altimeter data analysis for the oceans around South Africa. J Geophys Res 95:2991-3006

Warham J (1996) The behaviour, population biology and physiology of the petrels. Academic Press, London

Waugh S, Weimerskirch H, Cherel Y, Shankar U, Prince PA, Sagar P (1999) The exploitation of the marine environment by two sympatric albatrosses in the Pacific Southern Ocean. Mar Ecol Prog Ser 177:243-254

Weeks SJ, Shillington FA (1994) Interannual scales of variation of pigment concentrations from coastal zone colour scanner data in the Benguela Upwelling system and the Subtropical Convergence zone south of Africa. J Geophys Res 99: 7385-7399

Weimerskirch H (1999) The role of body condition in breeding and foraging decisions in albatrosses and petrels. In: Adams NJ, Slotow RH (eds) Proc 22nd Int Ornithol Congr, Durban, 16-22 August 1998. Birdlife South Africa, Johannesburg, p 1178-1189

Wiebe PH (1982) Rings of the Gulf Stream. Sci Am 246:50-60

Wiebe PH, Youce TM (1992) Introduction to interdisciplinary studies of Kuroshio and Gulf Stream rings. Deep-Sea Res 39:v-vi

Submitted: December 5, 2000; Accepted: March 1, 2001

Proofs received from author(s): July 13, 2001 